\title{
THE CZECH - SLOVAK RELATIONSHIPS IN THE SCHOOL POLICY IN THE VEARS OF 1918-1939 AND THE PERSONNEL ISSUE
}

Czech-Slovak relations are an important component in the history of our nations. In the historical context they were developed actively in the 1920's. The relations at these levels were mutually influenced and brought about several positive elements to the national heritage. As a consequence of the formation of the Czechoslovak Republic in 1918, there was a thorough spiritual and cultural renewal of the Slovak nation, which included the creation of a network of schools of all grades. The process of its building was not straightforward. It was connected with many obstacles and problems that demanded strategic and operative solutions. This article deals with the reconstruction of Czecho-Slovak relations in school politics in the years 1918-1939 in terms of personnel issues.

Keywords: Czech-Slovak relations, school policy, personnel issues.

\section{Introduction}

The problem of Czech-Slovak relations is now open. It creates a space for the explorations of the relations in the area of educational policy, while the Czech intelligence in Slovakia during the existence of the first Czechoslovak Republic can be seen in a new, broader context, without ideological restrictions, so even today this problem enables to observe new connections and insights on the issues of Czech-Slovak relations and Czech intelligence operation in Slovakia during the existence of the first Czechoslovak Republic.

\section{Mutual State, Mutual History and Czechoslovakism}

The establishment of the Czechoslovak Republic in 1918 and the following period of two decades represented a breakthrough for Slovakia. The Slovak nation lagged behind the developed parts of the Habsburg monarchy economically, culturally and educationally, which was a result of the Austro-Hungarian Compromise of 1867. In addition to the economic downturn, a significant population decline was indicated in the last census statistics in Hungary in 1910.

The First World War deepened the conflicts within the Habsburg monarchy and it also opened the way to solve the political problems of the oppressed nations and nationalities. At the end of 1918, thousands of Slovaks were abroad among the victorious allies. The most active of them joined the revolt against the Hungarian domination for freedom of their people.
At the end of the war, a joint Slovak and Czech resistance was formed and the idea of common state based on the language and Slavic closeness and traditionally good neighborhood in the region of Central Europe was born. Despite many questions and controversies, the birth of the idea of Czechoslovakism, which was at that time declared at home and among the members of foreign resistance, is currently considered as a victory of freedom. V. Srobar, one of the most active of the Slovak politicians, initially defined Slovaks as a Hungarian line of the Czechoslovak - Hungarian tribe, then later as a segment of the Czech-Slovak nation. Professor T. G. Masaryk, the philosopher and ideologist of the common state, declared that the Czech-Slovak nation, at that time as a Czechoslovak nation succeeded abroad. The idea of Czechoslovakism was accepted by Slovaks because it was a clear starting point for solving of their national problems with Hungarians. V. Srobar actually stated at that time that it was political nation ideologically and conceptually formed at an ad hoc basis for the coexistence with Czechs. The aim of it was to form an independent Czechoslovak state. It was legislatively based on the Act No. 11/1918 Coll. stating that the Czechoslovak state was established by the National Committee, "in the name of the Czechoslovak nation" [1]. The idea of the Czechoslovak state was founded by Czechs. However, it has to be acknowledged that it was a great achievement of the Czech politicians and the Czech nation that they gave up the idea of declaring of pure "Czechism" in the process of formulating this idea. In 1916, E. Benes stated: "In today's international situation we could hardly discuss the question of an independent Bohemia without Slovakia and the

\footnotetext{
* Jarmila Zacharova

Faculty of Humanities, University of Zilina in Zilina Slovakia

Email: jarmila.zacharova@fhv.uniza.sk
} 
idea of an independent Slovakia without Bohemia we could not raise at all" [2].

On the basis of the fact that the Czechoslovak state existed there was an implication of the existence of history of that state, thus, Czechoslovak history has existed at least since 1918. There was a complication with the question whether the Czechoslovak history existed earlier. From the fiction about the existence of the Czechoslovak it would follow that Slovak history was a regional part of Czechoslovak history. However, if the Slovaks were a separate nation, they would have their own history that is different from the history of Czech [3]. The idea of the common history of Czechs and Slovaks, or of the notion that they had in common a few points, was maintained by Vaclav Chaloupecký, who was Head of the historical seminar at Comenius University in Bratislava, later its dean and rector. In the work Old Slovakia he tried to prove the assumption that the area of today's western Slovakia was inhabited by "Slavs and Czechs" (Sclavi et Boemi) [4]. The continuity of Czechoslovak history was proved by the historian Kamil Kroft who also worked at Comenius University in Bratislava. In the work of Czechs and Slovaks before their national unification, he demonstrated their shared history in the so-called Czechoslovak national story that began in the Great Moravia and ended in 1918, joining the Czechs and Slovaks in one State [5]. Among Slovak historians who supported the idea of a single history were Branislav Varsik and Daniel Rapant. Nevertheless, Rapant later refused the concept of shared history and in the study of Czechoslovak history, he showed certain effort to their "spasmodic" integration into Czech history. He regarded The Concept of continuous Czechoslovak history as a political order [6].

The new state was founded in an exposed area where all the power interests of neighboring countries met. It was tendentiously stated that it had been founded without any tradition of statehood and therefore it was an artificial state. It was said that this state connected the inhomogeneous units and disrupted the power relationships and the balance in Europe. These efforts were directed with the purpose to undermine the stability and unity of the young state.

\section{School policy in Slovakia and the personnel issue}

The Slovak culture including education was to become one of the important factors in forming of the Czech-Slovak statehood. The idea that "Slovakia can grow into the life of Czechoslovakia only by developing its own cultural life" [7] reflected the reality of that time. But at the same time, there was a contradictory reality not seen by the official government circles and this reality was disguised by the fiction of a homogeneous Czechoslovak nation and culture which became evident in the 1930's.

The origin of new state brought about also the formation of new social - political and administrative structures. On
November 2, 1918, the Office for Administration of Education and Culture was created by the Act No. 2/1918 Coll. [8]. A. Stefanek, who worked as an editor of The National Newspapers in Prague was authorized in the position of the Education Commissioner for Slovakia on December 10, 1918. His task was to prepare the reorganization of the Slovak educational system. The Interim Government headed by V. Srobar fully accepted his appointment [9]. Stefanek worked as a government officer in the Educational Department of the Ministry of Education and Culture in Bratislava. All the activities of this department were liable to V. Srobar who was a Minister Plenipotentiary for the administration of Slovakia. A. Stefanek was a supporter of the idea of the Czech-Slovak solidarity and a spirited enthusiast of building Czechoslovakia. Although he did not complete the education as a teacher, he was familiar with the school situation in Slovakia and its inherited problems, which were a result of the previous Hungarian governments' activities.

The situation in the educational system in Slovakia was critical. After the establishment of Czechoslovakia, there were 3, 298 Hungarian primary schools, 140 Slovak, 7 German and 186 mixed language schools in Slovakia. The task to introduce the Slovak language to schools became very resonant [10]. The Interim Government abolished the teaching of the Hungarian language in Slovak towns and villages on November 6, 1918. According to the Act of December 10, 1918, Article 3, the Slovak language became the official language of Slovakia.

The staff of the Department of Education set the basic priorities whereby their starting point was the statistics of illiteracy from 1910. According to it, there were, for example, up to $67.9 \%$ illiterates in the Orava region, $62.1 \%$ in the Trencin County, $69.9 \%$ in the Spis region, $58.6 \%$ in the Saris region and $61.1 \%$ in the Zemplin region [11]. A. Stefanek's conceptions were associated with the compulsory school attendance and with a completion of a democratic educational system at all levels in towns and villages. The quick liquidation of illiteracy and school administration takeover in Slovakia became a categorical imperative. There was a need to occupy official posts with proCzechoslovak oriented staff. The Department in cooperation with the Department of the Ministry of Education and Culture replaced the staff at 37 inspector's posts during 1919 and it continued also in the following year. Each inspector was given a Czech teacher and counselor [12].

The lack of teachers became evident immediately after the foundation of the Czechoslovak Republic. On the one hand, it was the result of the departure of Hungarian teachers and professors from Slovakia who did not want to take a vow a primary teacher's oath to the newly established state according to the Government Regulation No. 495 of August 28, 1919. On the other hand, the graduates of teacher institutes who declared their support to the Slovak nation were educated in the Hungarian language. 
V. Srobar said about the situation in the Slovak educational system that they found here "... about 300 loyal Slovak teachers for primary schools and about 20 secondary school Slovak teachers while they had known just a small part of them from the previous periods. More than 4,000 elementary schools and all secondary schools and schools of higher education were in the hands of Hungarians, Magyarones (Slovak renegades) or half-Slovaks. We can claim with confidence that except for a few schools where children were taught in Slovak by a few mostly Evangelical teachers everywhere else they were taught in the Hungarian language, both in word and spirit [13]. The solution of the problem with the teaching staff became one of the most important tasks in the school department. The Minister Plenipotentiary for the administration of Slovakia V. Srobar, a government officer A. Stefanek and a government officer of the Ministry of Education and Culture J. Vlcek were the authors of the idea of the arrival of Czech teachers to Slovakia. The lack of skilled staff was solved in a similar way as in other branches of the Civil Service [14]. According to A. Stefanek, the task of the Department was "to fill schools with the Czechoslovak element. Not only with the Slovak one, i.e. by the staff speaking the Slovak language a bit but by the staff respectful to the Czechoslovak state" [15]. This goal was legally supported by the Act No. 605/1919 Coll. dated 29 $9^{\text {th }}$ October 1919 and it enabled to decree a civil servant, teacher or professor to work at any place in Czechoslovakia [16].

The government officer A. Stefanek and the department in Bratislava were appointed to organize the transfer of teachers from Bohemia and Moravia to Slovakia. The problem of quantity and professional quality of the teachers in the Slovak educational system was solved by the presence of Czech teachers numbering 1400 [17]. Their number was gradually complemented by Slovak graduates. The approach to filling of teaching jobs was not always standard and, therefore, it was met with negative responses.

There was a large migration throughout the existence of Czechoslovakia. It was a new stage in the development of CzechSlovak relations which, as to their importance, went beyond any previous contacts. Czech intelligentsia helped the Slovak nation to establish itself among the developed modern nations in Europe. As early as the first year of the young state, A. Stefánek acknowledged the positive influence of the Czech teachers on building of the Slovak educational system in the Budget Committee Report on the state budget of the Czechoslovak Republic for 1919: "The Czech teachers proved themselves worth and their activities and influence has been sensed everywhere they had come. I am just saying that during seven months we have organized and filled up about 70 secondary, vocational and higher secondary schools with good Czech professors and teachers; then we settled down several hundreds of Czech teachers at primary schools" [18].

It is clear that after 1918, Slovakia could not do without the help of Czech intelligentsia. On the other hand, it must be admitted that the Czechoslovak government sent people to
Slovakia who were sometimes not needed, which caused the problem - the so-called solving of the Czech question. The term "Czech question" and solving of the Czech question are terms related to the terminology of that period; they are technical terms [19]. The solution of the so-called Czech question became one of the essential idea of the Hlinka's Slovak People's Party. The basis of their program was expressed by two slogans: "Slovakia to Slovaks!" and "In Slovakia, speak Slovak" (free translation). It consisted of the idea that the civil servants of the Czech nationality should have been transferred from Slovakia and this would have vacated working places for unemployed Slovak intelligentsia.

It was stated on the argument that the representation of Slovaks in Czechoslovakia government is inadequate. Divergent views were also represented by the Czech officers and teachers in Slovakia. Konstantin Culen wrote in 1944 with regard to this: "It is certain that Slovakia would not exist without Czech help. This is a fact that cannot be changed. But this aid came too strong" [20]. Creating an atmosphere of nationalist tensions in society helped to recruit followers for Hlinka's Slovak People's Party program. The argument that the Czechs took Slovaks jobs, "Czechs take Slovaks bread", was very effective. This was mainly related to jobs like Czech officers and teachers who were definitively nominated.

When on October 6, 1938 the Hlinka's Slovak People's Party took over the political power in Slovakia, it launched this program. The first steps were made in the field of language rights. On October 10, 1938, the President of the Autonomous Government J. Tiso published the Regulation No.1/1938 according to which the Slovak language was the only official language in Slovakia. The regulation got into the Constitutional Law on the Autonomy of Slovakia No. 299/1938 of the Collection of Laws and Regulations [21]. Some Czech began to actively teach in Slovak, but the Regulation also provoked demonstrative resistance, e.g. Czech professors from Comenius University continued to lecture in Czech. Professor of Law Zdenek Peska rejected the amendment language law, which Slovak university students, who were associated with the Hlinka academics Club, considered as provocation. Complaints were peaking. An incident was recorded in connection with the laying of the foundation stone for the student dormitory Lafranconi in Bratislava. On a festival President Dr. Eduard Benes spoke Slovak, while Rector of Comenius University professor Wroclaw Busek spoke Czech, which was considered as the devaluation of the Slovak language [22]. The situation for the Czechs in Slovakia was not developing favorably. In autumn of 1937 Hlinka academics Club organized a mass protest against a Czech professor who refused to lecture in Slovak. The so-called national committees were coming into existence and they were "revolutionary" casting out Czechs and Jews from Slovakia with the help of the Hlinka Guards. There were anti-Czech demonstrations. In Bratislava, students and the Hlinka Guard supporters from the Svorad dormitory provoked riots and prohibited Czech professors to lecture at Comenius 
University [23]. Anti-Czech tendencies were fuelled by the contemporary press, especially by the periodicals The Slovak, The Slovak Language and The Guardsman as well as the Vienna Radio Broadcasting which broadcast in Slovak and called for a radical solution of the Czech question, i.e. for the banishment of all the Czechs from Slovakia [24]. The collegiate relationships between Czechs and Slovaks in staffrooms also changed. The contacts were restrained to a minimum; there were even attempts to instigate students against Czech teachers by their Slovak colleagues. "What to say when Slovak professors instigate students against Czech professors and encourage them not to believe Czech professors and to report all the anti-Hlinka manifestations? What to say when a young Slovak professor under the pretence of Scouting invites pupils to meetings where they discuss politics, i.e. antiCzech issues; where he asks questions about hated Czechs - what they said again and he gathers accusatory materials against them which he uses for anti-Czech and even personal attacks against them in the newspapers?" [25]. Typical relationships between Slovak students and Czech teachers were crooked by several factors. The number of attacks in the press, radio and at demonstrations increased. Many students of higher classes became members of the Hlinka Guard, where they received direct instructions to watch Czech teachers and professors and recorded any anti-Slovak statements. The result of the status disparagement of teachers and professors was the decline of students' discipline. Czech teachers and professors could hardly protest, if students, members and mainly top members of the Hlinka Guard were called out of lessons because of the service in the Hlinka Guard [26]. The situation escalated so much that "... students refuse to fulfill their tasks ... they talk about unwelcome, uneasy professors who have to be discharged from Slovakia, or ... at the moment when a Czech professor is to come into a classroom, they yell the Hlinka Guard political slogans uproariously and sing lilts such as: the Czech and the Jew - the same vermin ... the Czech into the sack, the sack into the water ..." (free translation) [27].

The situation in Slovakia was permanently complicated - to the disadvantage of Czech teachers, and, therefore, most of them tried to leave for Bohemia and Moravia. After the announcement of the independent Slovak Republic on March 14, 1939, the Government accepted a resolution on dismissal of all employees and workers in public offices, institutions and businesses on March 18, 1939 because they were not of the Slovak nationality. There were exceptions for those whose services were described as "absolutely necessary" [28]. Following the Slovak government decree dated from March 18, 1939, it was ordered to dismiss every teacher who was not of Slovak nationality from the school service on April 30, 1939 [29]. The explosive and hostile social atmosphere in Slovakia convinced the majority of Czech teachers and professors of the necessity of rapid departure. Although many of them had worked here for two decades, the seditious antiCzech policy did not offer them any other solution.

\section{Conclusion}

The relations between Czechs and Slovaks during the first two decades were evolving with different intensity, and were characterized by constituting of two separate nations living in one state, connected with signs of resistance and even with grudge for the Czechs in Slovakia. This process culminated in the years 1938 - 1939 when their position significantly changed. The activities of anti-Czech party supported unhealthy, hostile atmosphere against Czech teachers and professors at Slovak schools. And although many of them spent the most active years of their professional life in Slovakia, under the pressure of legislative changes, they were gradually leaving. Despite a brought to boil Despite an escalated socio-political situation in Czechoslovakia at the end of the 1930's, the engagement of Czech teachers and professors in Slovakia can be positively evaluated. They are responsible for shaping of the democratic spirit of Slovak schools and contributed to the overall development of the Slovak nation. They laid foundations not only for education, but also for science. They raised the first generation of Slovak intelligence, and therefore their professional and human trace in Slovak Education and Slovak Science is indelible.

\section{References}

[1] Act No. 11/1918, on the establishment of an independent state of Czechoslovakia on the 28 October 1918, Amount II. (in Czech), Collection of Laws and Regulations of the Czechoslovak state. Prague : State printer, 1918, p. 2.

[2] BENES, E.: Czechoslovak independence II /5 (in Czech), Paris, 1916.

[3] RYCHLIK, J.: Czechs and Slovaks in the 20 th century. Cooperation and Conflicts 1914 - 1992 (in Czech), Prague : Vysehrad, 2012, 520 p. ISBN 9788074291333.

[4] CHALOUPECKY, V.: Old Slovakia (in Czech), Bratislava : Comenius University, 1923.

[5] KROFTA, K.: Czechs and Slovaks before its National Unification (in Czech), Prague : Orbis, 1932.

[6] RAPANT, D.: Czechoslovak History. From Prehistory to the Present (in Czech), Almanac to the $60^{\text {th }}$ Birthday of prof. Josef Pekar, Prague : Historic club, 1930. 
[7] Slovak Looks (in Slovak), vol. 40, No. 6-8, 1924, p. 48.

[8] Act No. 2/1918 on the establishment of the highest administrative offices in Czechoslovakia of 2 November 1918 (in Czech), Part I of the Collection of Laws and Regulations of the Czechoslovak state, Prague : State printer, 1918. p. 1.

[9] SROBAR, V.: Exempt Slovakia. Memory from the period 1918-1920's (in Slovak), vol. 1, Prague, 1928.

[10] KALOUSEK, B.: Dr. Ivan Derer and National Education in Slovakia (in Slovak), Bratislava, 1935.

[11] STEFANEK, A.: Education in Slovakia (in Slovak), Bratislava, 1926, 22 p.

[12] Slovak National Archives Bratislava, Fund A. Stefanek (in Slovak), carton 15, III, inventory number 687.

[13] Slovak National Archives Bratislava, Fund A. Stefanek (in Slovak), carton 12, inventory number 655.

[14] KRAJCOVICOVA, N.: Czech Employees in the State Services in Slovakia in the First Years after the Creation of Czechoslovakia (in Slovak), Czechoslovakia from 1918 to 1938. The fates of democracy in Central Europe, vol. 1, Proc. of intern. scientific conference, Prague : Institute of History, 1999, 179-184.

[15] Slovak National Archives in Bratislava, Fund A. Stefanek (in Slovak), carton 15, III, inventory number 687.

[16] Act No. 605/1919 about the principles according to which the general and civil schooling can be ordered to any service location within the territory of the Czechoslovak Republic from the 29 October 1919 (in Czech). CXXVIII amount. Collection of Laws and Regulations of the Czechoslovak state, Prague : State printer, 1919, p. 935.

[17] KAZMEROVA, L.: The Evolution of the Structure of Education in Slovakia in 1918- 1938 (in Slovak), ZEMKO, M., BYSTRICKY, V. (ed.) Slovakia in Czechoslovakia from 1918 to 1939. Bratislava: Veda, 2004, 688 p., ISBN 80-224-0795 - X.

[18] Czech Teachers (in Czech), [online]. [accessed 2007-03-22]. Accessible on the Internet: <www.psp.cz/eknih/1918ns/ps/ stenprot/059schuc/s059002.htm>.

[19] RYCHLIK, J.: To the Question of the Status of the Czech Population in Slovakia in 1938-1945 (in Czech). Historical magazine, vol. 37, No. 3, 1989, p. 404.

[20] CULEN, K.: Czechs and Slovaks in Czechoslovakia State Services, $2^{\text {nd }}$ edition (in Slovak), Trencin : Ivan Stelcer, 1994

[21] Act No. 299/1938 Constitutional Law on Slovak Autonomy of the 22 November 1938. Figure 99 (in Czech), Collection of Laws and Regulations of the Czechoslovak state, Prague : State Printer, 1161-1164.

[22] RYCHLIK, J.: Czechs and Slovaks in the 20th century. Cooperation and conflicts 1914 - 1992 (in Czech), Prague : Vysehrad, 2012,520 p., ISBN 9788074291333.

[23] JIRASEK, J.: Slovakia at the Crossroads 1918-1938 (in Czech), Brno, Oct, 1947, 189 p.

[24] MUTNANSKY, L.: Slovak Revolution on the Waves of Ether (in Slovak), Bratislava, 1942.

[25] Pedagogical Museum of J. A. Commenius in Prague, Central Association Fund of the Czechoslovak professors (in Czech), inventory number 252/65-33P22/2

[26] MATULA, P.: The Czech High School Professors in Slovakia 1918 to 1938 (in Slovak), Presov : Michael Vasek Publishing, 165 p., ISBN 80-7165-582-1.

[27] Pedagogical Museum of J. A. Commenius in Prague, Central Association Fund of the Czechoslovak professors (in Czech), inventory number 252/65-33P22/35.

[28] Slovak National Archives Bratislava, Fund Office of the Presidency of the Government of the Slovak Republic (in Slovak), signature 9209/39, the letter of the Presidium of all ministries of March 20, 1939.

[29] Layoffs of Czech nationality Teachers from school services in Slovakia, 1939, School Administration in the Roman and Greek Catholic Bishop's Offices in Slovakia (in Slovak), Bratislava: Unia, 1939, vol. XI, No. 4, 33-34. 